\title{
Sumatra Land Surface Temperature Increase
}

\author{
M Munawar ${ }^{1,2, *}$ T A E Prasetya ${ }^{1,3} \mathrm{R}$ McNeil $^{1,4} \mathrm{R} \mathrm{Jani}^{5}$ \\ ${ }^{1}$ Research Methodology Department, Faculty of Science and Technology, Prince of Songkla University, Pattani \\ Campus, Muang Pattani, 94000 Thailand \\ ${ }^{2}$ Statistics Department, Faculty of Mathematics and Science, Syiah Kuala University, Jl. Syech Abd.Rauf, Kopelma \\ Darussalam, Banda Aceh, Aceh 23111, Indonesia \\ ${ }^{3}$ Health department, Faculty of Vocational Studies, Universitas Airlangga, Indonesia \\ ${ }^{4}$ Centre of Excellence in Mathematics, Commission on Higher Education (CHE), Ministry of Education, Ratchathewi, \\ Bangkok, 10400 Thailand \\ ${ }^{5}$ Ungku Aziz Centre for Development Studies, Faculty of Economics \& Administration, University Malaya, Malaysia \\ *Corresponding author. Email: munawar@unsyiah.ac.id
}

\begin{abstract}
Climate change in Sumatra island is likely a result of widespread land-use changes by the plantation industry. This study aims to investigate trends in land surface temperatures in Sumatra island. Land surface temperatures from 2001 2020 were downloaded from the National Aeronautics and Space Administration moderate resolution imaging spectroradiometer Terra satellite and divided into 5 regions and 45 sub-regions spread equally across the island. The statistical method that used to analyzed the data was cubic spline and multiple regression. The seasonal pattern and variation in the land surface temperature were examined using a cubic spline method and the seasonally adjusted land surface temperature was analyzed using a multiple regression model. On average, the land surface temperature on Sumatra island significantly increased over the ten years by $0.076^{\circ} \mathrm{C}$ with a $95 \%$ confidence interval of $[0.010$, $0.141]^{\circ} \mathrm{C}$.
\end{abstract}

Keywords: Climate change, Land surface temperature, Cubic spline, Sumatra island.

\section{INTRODUCTION}

Global warming and climate change are global problems that are currently being discussed with various disciplines trying to find solutions [1]. The temperature increase is an important indicator of climate change. It can cause a rise in sea levels, escalate the spread of disease, and result in food deficiency due to crop failure [2], [3].

A study shows that the world will experience a temperature increase probable to reach $1.5^{\circ} \mathrm{C}$ between 2030 and 2052 [4]. Temperatures in the Southeast Asia region are predicted to continue to increase with average temperatures increasing every decade since 1960 [5]. In Indonesia, the temperature is projected to become warmer by $0.2-0.3^{\circ} \mathrm{C}$ per decade, and Sumatra and Borneo islands will change in the season[6]. Sumatra island relies on agriculture and fishery products as its main source of income. Climate change in Sumatra island is believed to be caused by land-use change by the plantation industry [7]. Therefore, this research will examine the seasonal pattern and the increased variation of Land Surface Temperature (LST) in Sumatra island.

\section{METHODS}

Sumatra island is divided into 5 regions with each consisting of 9 equally spread subregions $95 \mathrm{~km}$ apart to avoid overlap and spatial correlation. LST was downloaded from the National Aeronautics and Space Administration moderate resolution imaging spectroradiometer (NASA MODIS) Terra satellite from 2001 to 2020 [8].

The seasonal pattern of LST was examined through the combination of a cubic spline model and a linear regression model as shown below [9]:

$a+b t+\sum_{k}^{p-3} c_{k}\left[\left(t-t_{k}\right)_{+}^{3}-d\left(t-t_{p-2}\right)_{+}^{3}+e\left(t-t_{p-1}\right)_{+}^{3}-f\left(t-t_{p}\right)_{+}^{3}\right]$ 
The trend of LST was analyzed using a multiple linear regression model with $95 \%$ confidence intervals of the changes displayed for each region [10]. The graphical and statistical methods were analyzed using the $\mathrm{R}$ language and environment [11].

\section{RESULT AND DISCUSSION}

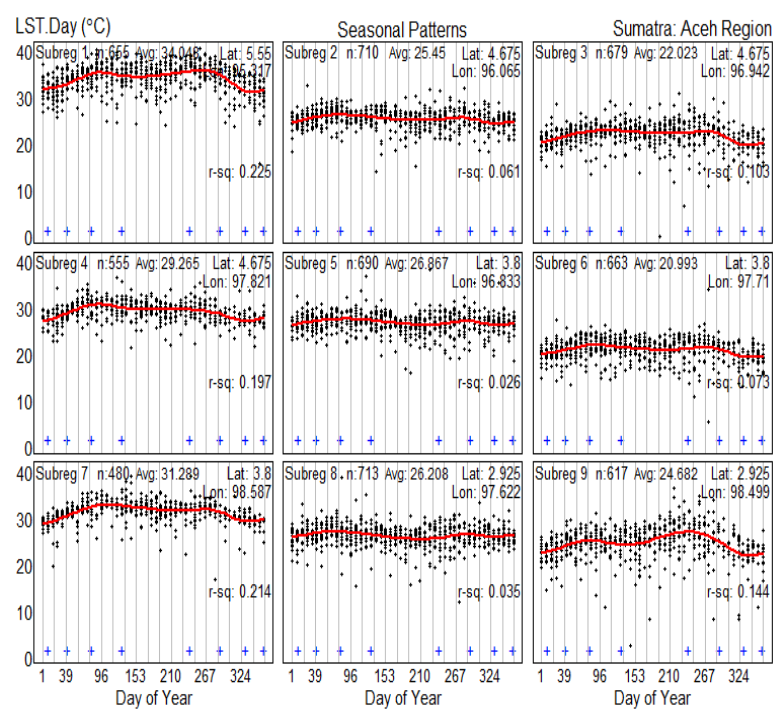

Figure 1 Aceh region seasonal pattern.

Figure 1 shows the seasonal pattern for subregions 1 - 9 in the Aceh region. The red line is the cubic spline showing some low variations, which may be due to the rainy season. The other four regions were also examined and the seasonal patterns were similar. The LST was then seasonally adjusted.

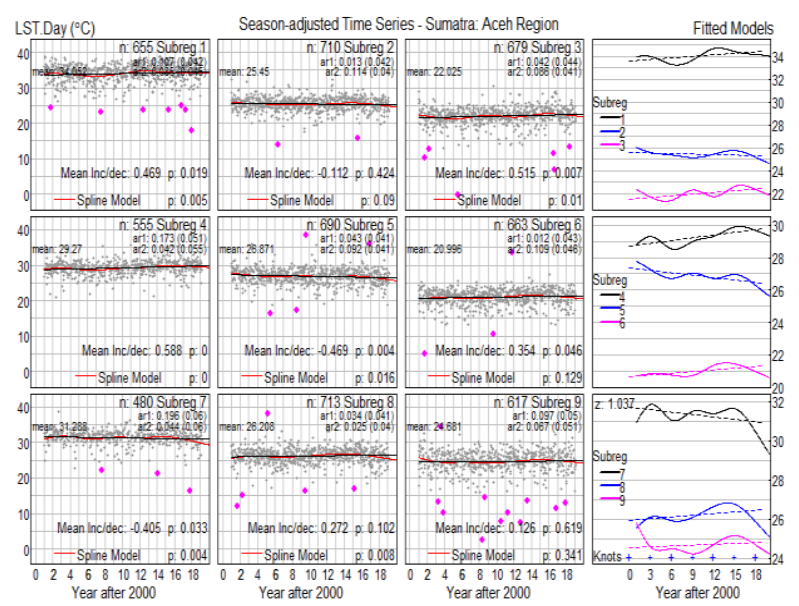

Figure 2 Seasonally adjusted time series of LST for the Aceh region.
In Figure 2, the seasonally adjusted LST time series indicated that the data has low autoregressive coefficients ( $a r_{1}$ and $\left.a r_{2}\right)$, indicating that the time series of daily temperatures were independent. The right panel of the figure shows the variation for each region, using the 7 knots (solid lines) of the cubic spline model, which indicate that the LST of subregions 1, 3, 4, 6 increased, sub-regions 5 and 7 decreased, subregion 2 slightly decreased, and subregions 8 and 9 slightly increased. The zero knots (dashed line) on the right panel also confirm the changes for each subregion. Overall, the LST of the Aceh region was stable with $\mathrm{z}=1.037$. A similar figure was also reconstructed for the rest of the regions.

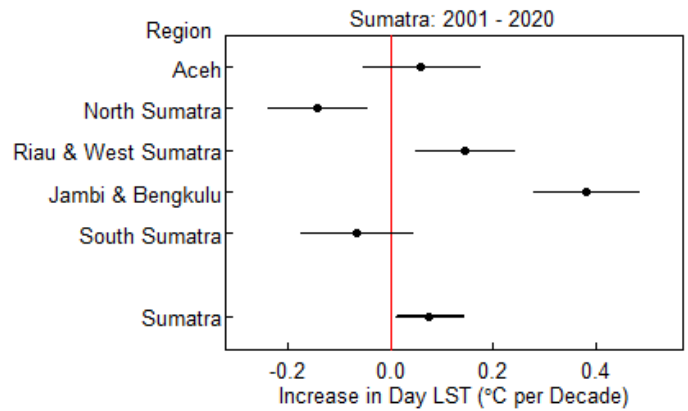

Figure 3 Means and 95\% confidence intervals of LST on Sumatra island.

The changes in LST for each region are shown in Figure 3. LST in Riau \& West Sumatra and Jambi \& Bengkulu significantly increased while in North Sumatra it significantly decreased. LST in North Sumatra decreased by $-0.141{ }^{\circ} \mathrm{C}$ per decade with $95 \% \mathrm{CI}$ [-0.237, -0.045], Riau \& West Sumatra, Jambi \& Bengkulu increased by $0.145^{\circ} \mathrm{C}$ per decade with CI $[0.050,0.240]$, and $0.382^{\circ} \mathrm{C}$ per decade with CI [0.279, 0.484], respectively. Overall, the average LST in Sumatra significantly increased by $0.076{ }^{\circ} \mathrm{C}$ per decade with $95 \%$ CI [0.010, 0.141]. 


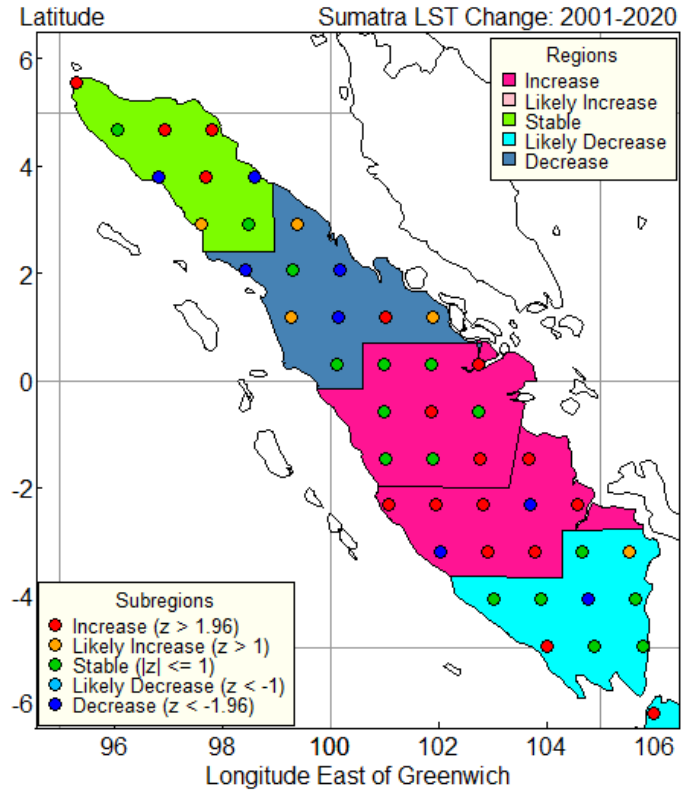

Figure 4 LST changes in Sumatra from 2001-2020.

Figure 4 displays the LST changes for each region of Sumatra. The LST in Aceh was stable (green), North Sumatera decreased (steel blue), Riau \& West Sumatra and Jambi \& Bengkulu increased (pink) and the South of Sumatra slightly decreased (cyan).

The stable LST in Aceh contrasts with a study in Banda Aceh which found that the region has the potential for an increase in temperature [12]. Other studies also illustrate the fact that there is an increase in temperature in the Aceh region due to land-use changes [13].

The northern and southern regions of Sumatra are areas that still have a large amount of forest and the northern region also has a fairly large water body in the form of an ancient volcanic lake (Toba Lake) [14]. The characteristics of the areas in the north and south of the island contribute to declining LST. Another study found that LST in the North Sumatra region increased, but in areas close to the water the LST decreased [15].

In contrast to other regions, the LST increased in Riau \& West Sumatra and Jambi \& Bengkulu regions. These areas have experienced an increase in temperature due to extensive land-use changes [16]. Massive deforestation is also one of the factors causing the increase in temperature in this region [17]. If control efforts are not well-managed in the process of land-use change and deforestation, the average LST is expected to continue to increase [18].

\section{CONCLUSION}

On average, the LST in Sumatra increased between 2001 and 2020. Climate science variables such as land elevation and normalized difference vegetation index should be investigated in further research.

\section{AUTHORS' CONTRIBUTIONS}

Munawar and Tofan developed the ide, computed, and analyzed the data with the methods and wrote the manuscript with support from Rhysa and Rohana. Rhysa and Rohana supervised the ide, methods, and findings. All authors contributed to the discussion of the result to the final manuscript.

\section{ACKNOWLEDGMENTS}

The authors gratefully acknowledge Professor Don McNeil for his invaluable assistance during this research. This study was supported by Thailand's Education Hub for ASEAN Countries (TEH-AC), Prince of Songkla University graduate school research grant, and the Centre of Excellence in Mathematics, commission on higher Education, Thailand.

\section{REFERENCES}

[1] B. R. Singh and O. Singh, Study of impacts of global warming on climate change: rise in sea level and disaster frequency. 2012.

[2] J. Gornall et al., "Implications of climate change for agricultural productivity in the early twentyfirst century," Philos. Trans. R. Soc. B Biol. Sci., vol. 365, pp. 2973-2989, 2010, doi: 10.1098/rstb.2010.0158.

[3] M. Measey, "Indonesia : A Vulnerable Country in the Face of Climate Change," Glob. Major. EJournal, vol. 1, no. 1, pp. 31-45, 2010.

[4] V. Masson-Delmotte, H.-O. Pörtner, J. Skea, P. Zhai, D. Roberts, and P. R. Shukla, Global Warming of $1.5^{\circ} \mathrm{C}$. Intergovernmental Panel on Climate Change., 2019.

[5] A. Prakash, "Boiling Point," Finance Dev., vol. 55, no. 3, pp. 22-26, 2018.

[6] M. Case, F. Ardiansyah, and E. Spector, "Climate Change in Indonesia Implications for Humans and Nature," 2007.

[7] S. D. Tarigan, "Land use changes and plantation crop development in selected provinces in Sumatra and Kalimantan," IOP Conf. Ser. Earth Environ. 
Sci. Pap., vol. 149, p. 012013, 2018, doi: doi :10.1088/1755-1315/149/1/012013.

[8] Z. Wan, S. Hook, and G. Hulley, "MOD11A2 MODIS/Terra Land Surface Temperature and Emissivity 8-Day L3 Global $1 \mathrm{~km}$ SIN Grid V006," NASA EOSDIS L. Process. DAAC, 2015, Accessed: Feb. 02, 2019. [Online]. Available: https://modis.ornl.gov/subsetdata/07Jan2019_11:5 7:25_749108552L28.658558L77.1221S81L81_M OD11A2/citation.bib.

[9] N. Wongsai, S. Wongsai, and A. R. Huete, "Annual seasonality extraction using the cubic spline function and decadal trend in temporal daytime MODIS LST data," Remote Sens., vol. 9, no. 12 , 2017, doi: 10.3390/rs9121254.

[10] Munawar, T. A. E. Prasetya, R. Mcneil, and R. Jani, "Pattern and Trend of Land Surface Temperature Change on New Guinea Island," Pertanika J. Sci. Technol., vol. 28, no. 4, pp. 1517-1529, 2020, doi: https://doi.org/10.47836/pjst.28.4.20.

[11] R. C. Team, "R: A Language and Environment for Statistical Computing," Vienna, Austria, 2018. https://www.r-project.org/ (accessed Feb. 02, 2019).

[12] A. Achmad, L. H. Sari, and I. Ramli, "A Study of Urban Heat Island of Banda Aceh City, Indonesia Based on Land Use/Cover Changes and Land Surface Temperature," Aceh Int. J. Sci. Technol., vol. 8, no. 1, pp. 41-51, 2019, doi: 10.13170/aijst.8.1.13060.

[13] A. Achmad, Zainuddin, and M. Muftiadi, "The relationship between land surface temperature and water index in the urban area of a tropical city," IOP Conf. Ser. Earth Environ. Sci., vol. 365, p. 12013, 2019, doi: 10.1088/17551315/365/1/012013.

[14] Lukman, M. S. Syawal, and M. Maghfiroh, "Sumatran major lakes: limnological overviews," IOP Conf. Ser. Earth Environ. Sci., vol. 535, p. 12064, 2020, doi: 10.1088/1755$1315 / 535 / 1 / 012064$.

[15] T. A. E. Prasetya, Munawar, S. Chesoh, A. Lim, and D. R. McNeil, "Different space characteristics of air temperature variation in North Sumatra Indonesia," J. Phys. Conf. Ser., vol. 1517, p. $12008, \quad 2020$, doi: $10.1088 / 1742-$ 6596/1517/1/012008.

[16] J. Merten et al., "Flooding and land use change in
Jambi Province, Sumatra: integrating local knowledge and scientific inquiry," Ecol. Soc., vol. 25 , no. 3 , p. 14,2020 , doi: $10.5751 /$ ES-11678250314 .

[17] C.-C. Chen et al., "Thermodynamic and Dynamic Responses to Deforestation in the Maritime Continent: A Modeling Study,” J. Clim., vol. 32, no. 12 , pp. $3505-3527$, May 2019, doi: 10.1175/JCLI-D-18-0310.1.

[18] P. O. Canziani and G. Carbajal Benitez, "Climate Impacts of Deforestation/Land-Use Changes in Central South America in the PRECIS Regional Climate Model: Mean Precipitation and Temperature Response to Present and Future Deforestation Scenarios," Sci. World J., vol. 2012, p. 972672 , 2012, doi: 10.1100/2012/972672. 